\title{
ENTREPRENEUR
}

\section{Jurnal Bisnis Manajemen Dan Kewirausahaan}

Program Studi Manajemen Fakultas Ekonomika dan Bisnis Universitas Majalengka

Published every January and July e-ISSN : (Proses), p-ISSN: 2723-1941

Available online https://ejournal.unma.ac.id/index.php/entrepreneur

\section{Pengaruh Pengendalian Intern, Kepatuhan Dan Integritas Manajemen Terhadap Perilaku Etis Karyawan Dalam Sistem Penggajian}

\author{
Melia Wida Rahmayani ${ }^{1}$ Yogi Ginanjar ${ }^{2}$ \\ Fakultas Ekonomika dan Bisnis Universitas Majalengka \\ Email : $\underline{\text { meliawidar@unma.ac.id }}$
}

ABSTRACT
This research is to find out the Internal control, Compliance, and the Integrity
management against of the ethical behaviour in payroll system both simultaneously or be
partial. The independent variable used in this research are internal control, adherence, and
integrity managment. While for dependent variable for ethical behaviour in payroll system.
The method used in this research are using a technique descriptive analysis and
verifikatif. A sample in this experiment to 59 people using simple random sampling
techniques. Technical data is a questionnaire. An instrument to test the validity of the data,
test and test reliabilitas normality data analysis of the data is the correlation, determianasi,
test hypotheses partial or be partial. Data processing using Statistical Product And Service
Solution (SPSS) versions 21 and Microsoft Excel in 2007.
The results of these studies show that a partial variable internal control and integrity
management have significant influence on Ethical Behaviour in Payroll System, and variable
compliance not have significant influence on Ethical Behaviour in Payroll System.
Simultaneously variable internal control, compliance, and integrity management have a
significant positive against of the ethical behaviour in payroll system.
The Keywords $\quad$ Internal Control, Compliance, Integrity Management, Ethical
Behaviour, Payroll System




\section{ENTREPRENEUR}

Jurnal Bisnis Manajemen Dan Kewirausahaan

Program Studi Manajemen Fakultas Ekonomika dan Bisnis Universitas Majalengka

Published every January and July e-ISSN : (Proses), p-ISSN: 2723-1941

Available online https://ejournal.unma.ac.id/index.php/entrepreneur

\section{PENDAHULUAN}

Tindakan penyimpangan dalam laporan keuangan ini merupakan salah satu tindakan kecurangan akuntansi. Tindakan yang dilakukan dapat berupa penghilangan jumlah atau pengungkapan dalam laporan keuangan untuk melabuhi pemakai laporan keuangan. Pada umumnya kecurangan akuntansi berkaitan dengan korupsi karena keterlibatan dalam beberapa unsur yang terdiri dari pengungkapan fakta-fakta menyesatkan, pelanggaran peraturan atau penyalahgunaan.

Agar tujuan perusahaan dapat tercapai dengan baik maka peranan sumber daya manusia yang potensial merupakan hal yang penting didalam kelangsungan hidup perusahaan. Peranan sumber daya yang potensial dapat tercapai apabila keseimbangan antara gaji dan upah (Siti Aisah, 2010). Selain itu gaji juga merupakan bidang yang menyebabkan pemborosan banyak sumber daya perusahaan karena inefisiensi atau pencurian melalui kecurangan (fraud).

Tingginya perilaku tidak etis dalam sistem penggajian yang dilakukan oleh karyawan disebabkan oleh informasi yang diterima manajemen tidak akurat, tidak relevan, tidak lengkap dan tidak tepat waktu sehingga menjadi penghambat bagi para pembuat keputusan dalam mengambil kebijakan yang tepat bagi pencapaian tujuan perusahaan. Oleh karena itu, diperlukan adanya pengendalian intern untuk mengarahkan, mengawasi, dan mengukur sumber daya suatu organisasi. Pengendalian ini berperan penting untuk mencegah dan mendeteksi kecurangan serta melindungi sumber daya organisasi, baik yang berwujud maupun tidak.

Pengendalian intern yang efektif sekalipun tidak menjamin kelangsungan hidup perusahan karena pengendalian ini mempunyai kelemahan, yakni dapat

dimanfaatkan oleh karyawan bersangkutan yang berkolusi untuk kepentingan pribadinya. Dengan demikian, pengendalian intern yang efektif saja tidak cukup untuk menghidari kecurangan yang dilakukan oleh karyawan.

Koordinator

OJK

Watch Andri Maulana meminta jajaran Kepolisian untuk segera mengembangkan penyidikan perkara dugaan pembobolan dana nasabah Bank Tabungan Negara (BTN). Khususnya terkait perkara pembobolan empat nasabah BTN dengan jumlah mencapai Rp 250 miliar.

Kasus itu, menurut Andri, mendesak untuk dikembangkan karena mustahil proses pembobolan ini dilakukan hanya oleh karyawan biasa tanpa sepengetahuan atasan, bahkan jajaran pimpinan bank pelat merah tersebut. Di duga kasus ini diatur bagian legal Bank BTN agar tingkat direksi tidak tersentuh. "Padahal pencairan dana dan penempatan dana yang jumlah ratusan miliar pasti dan wajib diketahui oleh direksi," (Tempo.com 7 September 2019).

Dari masalah ini Pengendalian intern memegang peran penting dalam organisasi untuk meminimalisir terjadinya kecurangan dan pengendalian intern yang efektif akan menutup peluang terjadinya pelaku tidak etis serta kecenderungan untuk berlaku curang dalam akuntansi. Dengan memiliki sistem pengendalian intern yang baik, seharusnya kecurangan tersebut dapat dicegah. Pengendalian intern adalah suatu proses yang dijalankan oleh dewan komisaris, manajemen dan personal lain entitas yang didesain untuk memberikan gambaran keyakinan memadai tentang pencapaian keandalan laporan, efektifitas dan efisiensi, dan kepatuhan terhadap hukum dan peraturan yang berlaku.

Siti Aisah (2010) menjelaskan bawa kegagalan penyusunan laporan keuangan yang disebabkan karena ketidaktaatan pada aturan akuntansi, akan menimbulkan 


\section{ENTREPRENEUR}

Jurnal Bisnis Manajemen Dan Kewirausahaan

Program Studi Manajemen Fakultas Ekonomika dan Bisnis Universitas Majalengka

Published every January and July e-ISSN : (Proses), p-ISSN: 2723-1941

Available online https://ejournal.unma.ac.id/index.php/entrepreneur

kecurangan perusahaan yang yang tidak dapat dideteksi oleh auditor. Dengan adanya ketidaktaatan tersebut, maka perusahaan harus membuat peraturan-peraturan secara tertulis baik aturan akuntansi maupun perusahaan. Dengan itu juga agar tujuan perusahaan berjalan dengan efektif dibutuhkan adanya kepatuhan pada hukum dan peraturan yang berlaku.

Faktor yang lainnya yang dapat mempengaruhi perilaku etis karyawan dalam sistem penggajian yaitu dengan adanya integritas manajemen dimana manajemen bertanggung jawab untuk menetapkan dan menyelenggarakan pengendalian intern.

Perilaku etis ( ethical behavior) perilaku yang sesuai dengan norma sosial yang diterima secara umum. Perilaku seseorang dalam suatu organisasi akan sangat dipengaruhi nilai-nilai, norma-norma moral dan prinsip yang dianutnya dalam menjalankan kehidupannya, yang kemudian bisa dianggap sebagai penentu kualitas individu tersebut. Semua kualitas individu tersebut ini nantinya akan dipengaruhi oleh faktor-faktor yang diperoleh dari luar kemudian menjadi prinsip yang dijalani dalam kehidupan dalam bentuk perilaku. Faktor-faktor tersebut adalah pengaruh budaya, pengaruh organisasi tempatnya bekerja dan pengaruh kondisi politik dan perekonomian global dimana dia hidup.

Dalam sistem perbankan di Indonesia, Bank Perkereditan Rakyat (BPR) memiliki peran yang penting yaitu memberikan pelayanan perbankan kepada usaha kecil atau usaha mikro dan sektor informal, terutama di daerah pedesaan.

Banyak faktor yang dapat mempengaruhi perilaku etis karyawan diantaranya menurut Hesti Arlich Arifiyani (2012) faktor yang dapat mempengaruhi
Perilaku etis karyawan dapat terjadi diberbagai tingkatan perusahaan dikarenakan adanya kepatuhan merupakan suatu spesifikasi, standar atau hukum yang telah diatur dengan jelas yang biasanya diterbitkan oleh lembaga atau organisasi yang berwenang dalam suatu bidang tertentu. Faktor yang lainnya yang dapat mempengaruhi perilaku etis karyawan dalam perusahaan yaitu dengan adanya integritas manajemen (Siti Aisah,2010). Permasalahnnya adalah sejauhmana kontribusi ketiga variabel tersebut mendorong terbentuknya perilaku etis karyawan khususnya dalam sistem penggajian pada PD BPR Sukahaji Kabupaten Majalengka untuk meminimalisir terjadinya kecurangan.

Dengan adanya uraian diatas bahwa pentingnya pengendalian intern, kepatuhan, dan integritas manajemen dan perilaku etis karyawan dalam setiap kegiatan perusahaan, maka peneliti tertarik untuk melakukan penelitian yang berjudul "Pengaruh Pengendalian Intern, Kepatuhan, dan Integritas Manajemen Terhadap Perilaku Etis Karyawan Dalam Sistem Penggajian Pada PD. BPR Sukahaji Kabupaten Majalengka".

\section{Permasalahan}

Berdasarkan uraian dalam latar belakang, masalah penelitian ini dapat dirumuskan sebagai berikut :

1. Bagaimana deskripsi pengendalian intern, kepatuhan dan integritas manajemen terhadap perilaku etis dalam system penggajian pada PD BPR Sukahaji Kabupaten Majalengka.

2. Seberapa besar pengaruh pengendalian intern, kepatuhan dan integritas manajemen terhadap perilaku etis 


\section{ENTREPRENEUR \\ Jurnal Bisnis Manajemen Dan Kewirausahaan}

Program Studi Manajemen Fakultas Ekonomika dan Bisnis Universitas Majalengka

Published every January and July e-ISSN : (Proses), p-ISSN: 2723-1941

Available online https://ejournal.unma.ac.id/index.php/entrepreneur

dalam system penggajian pada PD BPR

Sukahaji Kabupaten Majalengka.

\section{KERANGKA TEORITIS DAN HIPOTESIS}

Kecurangan laporan keuangan atau kecurangan manajemen merupakan salah saji atau penghilangan secara sengaja jumlah atau pengungkapan dalam laporan keuangan untuk mengelabui pemakai laporan keuangan. Salah satu laporan keuangan yang diselesaikan oleh bagian akuntansi dan ditangani oleh manajemen perusahaan secara langsung adalah pengelolaan gaji dan upah karyawan. Selain itu, gaji juga merupakan bidang yang menyebabkan pemborosan banyak sumber daya perusahaan karena inefisiensi atau pencurian melalui perilaku tidak etis dan kecurangan.

Tingginya perilaku tidak etis dalam sistem penggajian yang dilakukan oleh karyawan disebabkan oleh informasi yang diterima manajemen tidak akurat, tidak relevan, tidak lengkap dan tidak tepat waktu sehingga menjadi penghambat bagi para pembuat keputusan dalam mengambil kebijakan yang tepat bagi pencapaian tujuan perusahaan. Oleh karena itu, diperlukan adanya pengendalian intern untuk mengarahkan, mengawasi, dan mengukur sumber daya suatu organisasi.

Pengendalian Intern merupakan alat yang dapat digunakan dalam mencegah serta mengidentifikasi kecurangan atau fraud. Penelitian mengindikasikan pentingnya pengungkapan serta pencegahan terjadinya tindakan kecurangan dan menilai hubungan antara lingkungan pengendalian, penaksiran resiko, pengawasan, informasi dan komunikasi, audit internal serta pemantauan dengan prosedur pengendalian internal.

Menurut Wolk dan Tearney (dalam Siti Aisah, 2010) menjelaskan bawa kegagalan penyusunan laporan keuangan yang disebabkan karena ketidaktaatan pada aturan akuntansi, akan menimbulkan kecurangan perusahaan yang yang tidak dapat dideteksi oleh auditor. Dengan adanya ketidaktaatan tersebut, maka perusahaan harus membuat peraturan-peraturan secara tertetulis baik aturan akuntansi maupun perusahaan. Dengan itu juga agar tujuan perusahaan berjalan dengan efektif dibutuhkan adanya kepatuhan pada hukum dan peraturan yang berlaku.

Selain itu moralitas manajemen juga berpengaruh pada perilaku etisnya. Majemen bertanggung jawab untuk menyusun, melaksanakan dan mengawasi kegiatan perusahaan. Manajemen juga bertanggung jawab untuk mengembangkan secara efektif pengendalian intern organisasinya. Manajemen dapat mengabaikan kebijakan atau prosedur yang telah ditetapkan untuk tujuan yang sah seperti keuntungan pribadi manajer, penyajian kondisi keuangan yang berlebihan atau keuntungan semu. Contohnya adalah manajemen melaporkan laba yang lebih tinggi dari jumlah sebenarnya untuk mendapatkan bonus lebih tinggi bagi dirinya atau untuk menutupi ketidakpatuhannya terhadap peraturan perundangan yang berlaku. Padahal efektifitas pengendalian intern bersumber dari dalam diri orang yang melaksanakannya. Pengendalian intern yang memadai desainnya, namun dijalankan oleh orang-orang yang tidak menunjung tinggi integritas dan tidak memiliki etika, akan mengakibatkan tidak terwujudnya tujuan pengendalian intern. Oleh karena itu, tanggung jawab manajemen adalah menjunjung tinggi nilai integritas dan etika bisnis.

Maka dari penjelasan tersebut penulis dapat menyimpulkan bahwa pengendalian intern, kepatuhan dan integritas manajemen dapat dipengaruhi oleh perilaku etis karyawan. Beberapa peneliti 


\section{ENTREPRENEUR}

Jurnal Bisnis Manajemen Dan Kewirausahaan

Program Studi Manajemen Fakultas Ekonomika dan Bisnis Universitas Majalengka

Published every January and July e-ISSN : (Proses), p-ISSN: 2723-1941

Available online https://ejournal.unma.ac.id/index.php/entrepreneur

sebelumnya yang menyatakan bahwa ada keterkaitan erat antara pengendalian intern, kepatuhan dan integritas manajemen dengan perilaku etis karyawan. Seperti Annisa Fitriana (2010) dalam penelitiannya menyatakan bahwa pengendalian internal dan sistem kompensasi mempunyai dampak terhadap kecenderungan kecurangan, dimana perilaku etis karyawan sebagai gejalanya.

Sedangkan menurut penelitian Dallas (dalam Siti Aisah, 2010) bahwa semakin tinggi tingkat moralitas manajemen, semakin rendah perilaku tidak etisnya. Hal itu berarti tingkat moralitas manajemen yang tinggi akan memacu perilaku etis para karyawannya.

\section{METODELOGI PENELITIAN}

Metode penelitian yang digunakan adalah metode survey dengan pendekatan analisis deskriftif dan verifikatif. Data yang digunakan adalah data primer yang diperoleh dari responden.

\section{Operasionalisasi Variabel}

1. Variabel independen dalam penelitian ini yaitu:
a. Pengendalian Intern $\left(\mathrm{X}_{1}\right)$
Pengendalian intern sebagai suatu proses yang dijalankan oleh dewan komisaris, manajemen dan personal lain entitas yang didesain untuk memberikan keyakinan memadai tentang pencapaian tiga golongan tujuan berikut ini : (a) keandalan pelaporan keuangan, (b) efektifitas dan efisiensi operasi dan (c) kepatuhan terhadap hukum yang berlaku (IAI:2011:319.2) dalam Sukrisno Agoes (2012).
b. Kepatuhan $\left(\mathrm{X}_{2}\right)$

Pengujian kepatuhan (compliance test) atau sering disebut dengan pengujian pengendalian (test of control) dengan kata lain kepatuhan. Pengujian kepatuhan (compliance test) harus dilakukan di dalam perusahaan terhadap kebijakan dan prosedur tertulis tentang kelengkapan transaksi dan kepatuhan terhadap perundangundangan (Sukrisno Agoes, 2009:245).

c. Integritas Manajemen $\left(\mathrm{X}_{3}\right)$

Moralitas manajemen berpengaruh pada perilaku etisnya. Manajemen bertanggung jawab untuk menyusun, melaksanakan dan selalu mengawasi kegiatan perusahaan (Siti Aisah, 2010)

2. Variabel dependen dalam penelitian ini yaitu Perilaku Etis Dalam Sistem Penggajian

a. Perilaku Etis Dalam Sistem Penggajian (Y)

Perilaku etis adalah perilaku yang sesuai dengan norma sosial yang diterima secara umum. Faktor yang mempengaruhi perilaku etis yaitu budaya organisasi, kondisi politik dan perekonomian global. (Ricky W. Griffin, 2006:58).

\section{Populasi dan Sampel \\ Populasi}

Populasi dalam penelitian ini adalah karyawan PD. BPR Sukahaji Kabupaten Majalengka berjumlah 146 orang.

Sampel

Penelitian ini menggunakan teknik simple random sampling yaitu pengambilan sampel dari populasi secara acak tanpa 


\section{ENTREPRENEUR \\ Jurnal Bisnis Manajemen Dan Kewirausahaan}

Program Studi Manajemen Fakultas Ekonomika dan Bisnis Universitas Majalengka

Published every January and July e-ISSN : (Proses), p-ISSN: 2723-1941

Available online https://ejournal.unma.ac.id/index.php/entrepreneur

memperhatikan strata yang ada dalam populasi itu (Sugiyono, 2012:64).

\section{Analisis Data}

Analisis data pada penelitian ini yaitu uji instrumen penelitian yaitu uji validitas dan reliabilitas, transformasi data, uji asumsi klasik (uji normalitas, uji multikolinearitas, uji heteroskedastisitas), analisis regresi linier berganda, koefisien determinasi dan uji hipotesis dengan menggunakan aplikasi SPSS.

\section{Analisis Koefisien Determinasi}

Untuk mengetahui seberapa besar pengaruh koefisien determinasi digunakan rumus sebagai berikut (Sugiyono, 2014:231).

Keterangan :

$\mathrm{Kd}=$ Koefisien Determinasi

$\mathrm{r}^{2}=$ Nilai koefisien determinasi

\section{Uji Hipotesis}

\section{Uji Parsial}

Pengujian ini dilakukan dengan cara membandingkan $\mathrm{t}$ hitung dengan $\mathrm{t}$ tabel pada tingkat signifikan $\alpha 5 \%$ dengan $\mathrm{dk}=\mathrm{n}-1$.

$$
\mathrm{t}_{\text {hitung }}=\frac{r \sqrt{n-2}}{\sqrt{1-r^{2}}}
$$

Keterangan:

$$
\begin{array}{ll}
\mathrm{t}_{\text {hitung }} & =\text { Nilai } \mathrm{t} \\
\mathrm{r} & =\text { Nilai koefisien korelasi } \\
\mathrm{n} & =\text { Jumlah sampel }
\end{array}
$$

Berdasarkan rumusan masalah dan hipotesis maka dilakukan uji hipotesis dengan ketentuan sebagai berikut:

Hipotesis Pertama: Ada pengaruh antara batasan waktu audit terhadap kualitas audit.

Hipotesis Kedua: Ada pengaruh antara pengalaman terhadap kualitas audit.

\section{Uji Simultan}

Untuk pengujian secara simultan maka digunakan uji $\mathrm{F}$. Uji $\mathrm{F}$ adalah alat menguji variabel independen secara bersama terhadap variabel dependennya untuk

$$
\mathrm{Kd}=\mathrm{r}^{2} \times 100 \%
$$

meneliti apakah model dari penelitian tersebut sudah fit (sesuai) ataukah tidak sesuai. Dapat dihitung dengan rumus menurut

Sugiyono (2014:192) sebagai berikut :

$$
\mathrm{F}_{\text {hitung }}=\frac{R^{2} / k}{\left(1-R^{2}\right) /(n-k-1)}
$$

Keterangan:

$\mathrm{n}=$ Jumlah responden

$\mathrm{k}=$ Jumlah variabel bebas (independen)

$\mathrm{R}^{2}=$ Koefisien korelasi ganda 


\section{ENTREPRENEUR}

Jurnal Bisnis Manajemen Dan Kewirausahaan

Program Studi Manajemen Fakultas Ekonomika dan Bisnis Universitas Majalengka

Published every January and July e-ISSN : (Proses), p-ISSN: 2723-1941

Available online https://ejournal.unma.ac.id/index.php/entrepreneur

\section{Hasil dan Pembahasan \\ Hasil Uji Parsial (Uji t)}

Tabel 4.37

Coefficients ${ }^{\mathrm{a}}$

\begin{tabular}{|rl|r|r|r|r|r|}
\hline \multicolumn{1}{|l|}{ Model } & \multicolumn{2}{|c|}{ Unstandardized Coefficients } & \multicolumn{1}{c|}{$\begin{array}{c}\text { Standardized } \\
\text { Coefficients }\end{array}$} & \multirow{2}{*}{ Sig. } \\
\cline { 3 - 5 } & \multicolumn{1}{|c|}{ B } & \multicolumn{1}{c|}{ Std. Error } & \multicolumn{1}{c|}{ Beta } & & \\
\hline \multirow{4}{*}{1} & (Constant) & 16,913 & 7,116 & & 2,377 &, 021 \\
& Pengendlian Intern &, 279 &, 135 &, 280 & 2,060 &, 044 \\
& Kepatuhan &,- 123 &, 148 &,- 123 &,- 831 &, 410 \\
& Integritas Manajemen &, 506 &, 125 &, 508 & 4,056 &, 000 \\
\hline
\end{tabular}

a. Dependent Variable: Perilaku Etis Karyawan

\section{Sumber : Data Hasil SPSS 21 (Diolah}

Sendiri, 2021)

a. Berdasarkan tabel 4.37 diperoleh nilai t hitung untuk variabel pengendalian intern adalah sebesar 2,060 sedangkan t tabel sebesar 2,002 dengan tingkat signifikansi sebesar 0,044 oleh karena itu $\mathrm{t}_{\text {hitung }}>\mathrm{t}_{\text {tabel }}$ yaitu 2,060 $>2,002$ dan nilai signifikansinya $0,044<0,05$ maka Ho ditolak dan $\mathrm{Ha}$ diterima. Hal ini berarti pengendalian intern berpengaruh signifikan terhadap perilaku etis karyawan dalam sistem penggajian, sehingga hasil hipotesis pertama terbukti kebenarannya.

b. Berdasarkan tabel 4.37 diperoleh bahwa nilai $\mathrm{t}$ hitung untuk variabel kepatuhan adalah sebesar 0,831, sedangkan t tabel sebesar 2,002 dengan tingkat signifikansi sebesar 0,410 oleh karena itu $\mathrm{t}_{\text {hitung }}<\mathrm{t}$ tabel yaitu $0,831<$ 2,002 dan nilai signifikansinya $0,410>$ 0,05 maka Ho diterima dan Ha ditolak. Hal ini berarti kepatuhan tidak berpengaruh signifikan terhadap perilaku etis karyawan dalam sistem penggajian, sehingga hasil hipotesis kedua tidak terbukti kebenarannya.

c. oleh karena itu $t_{\text {hitung }}>t_{\text {tabel }}$ yaitu 4.056 $>2,002$ dan nilai signifikansinya 0,000 $<$ 0,05 maka Ho ditolak dan $\mathrm{Ha}$ diterima. Hal ini berarti integritas manajemen berpengaruh signifikan terhadap perilaku etis karyawan dalam sistem penggajian, sehingga hasil hipotesis ketiga terbukti kebenarannya.

d. Berdasarkan tabel 4.37 diperoleh nilai t hitung untuk variabel integritas manajemen adalah sebesar 4.056, sedangkan t tabel sebesar 2,002 dengan tingkat signifikansi sebesar 0,000 


\section{ENTREPRENEUR}

Jurnal Bisnis Manajemen Dan Kewirausahaan

Program Studi Manajemen Fakultas Ekonomika dan Bisnis Universitas Majalengka

Published every January and July e-ISSN : (Proses), p-ISSN: 2723-1941

Available online https://ejournal.unma.ac.id/index.php/entrepreneur

\section{Hasil Uji Simultan (Uji F)}

Tabel 4.38

ANOVA ${ }^{\mathrm{a}}$

\begin{tabular}{|ll|r|r|r|r|r|}
\hline \multicolumn{1}{|l|}{ Model } & Sum of Squares & df & Mean Square & F & Sig. \\
\hline \multirow{4}{*}{1} & Regression & 1903,928 & 3 & 634,643 & 8,993 &, $000^{\mathrm{b}}$ \\
& Residual & 3881,520 & 55 & 70,573 & & \\
& Total & 5785,448 & 58 & & & \\
\hline
\end{tabular}

a. Dependent Variable: Perilaku Etis Karyawan

b. Predictors: (Constant), Integritas Manajemen, Pengendlian Intern, Kepatuhan

Sumber : Data Hasil SPSS 21 (Diolah

Sendiri, 2021)

Berdasarkan kolom sig. (signifikan) pada tabel 4.38 hasil uji $\mathrm{F}$ diatas, diperoleh sig 0,000 lebih kecil dari profitabilitas 0,05 atau $0,05>0,000$ dan nilai $\mathrm{F}_{\text {hitung }}>\mathrm{F}_{\text {tabel }}$ yaitu 8,993 > 2,77 77 maka Ho ditolak dan Ha diterima. Hal ini berarti pengendalian intern, kepatuhan dan integritas manajemen bersama-sama berpengaruh secra signifikan terhadap perilaku etis karyawan dalam sistem penggajian,sehingga hipotesis ke empat terbukti kebenarannya.

\section{Pembahasan}

Pengaruh Pengendalian Intern Terhadap Perilaku Etis Karyawan Dalam Sistem Penggajian

Hasil penelitian variabel pengendalian intern terhadap perilaku etis karyawan dalam sistem penggajian dengan nilai $\mathrm{t}_{\text {hitung }}>\mathrm{t}$ tabel yaitu 2,060 > 2,002 dan nilai signifikansinya $0,044<0,05$ maka Ho ditolak dan $\mathrm{Ha}$ diterima. Hal ini berarti pengendalian intern berpengaruh signifikan terhadap perilaku etis karyawan dalam sistem penggajian pada karyawan sehingga hasil hipotesis pertama terbukti kebenarannya.

Hasil penelitian ini konsisten dengan penelitian Hesti Arlich Arifiyani (2012) yang melakukan penelitian di PT Adi Satria Abadi Yogyakarta. Variabel pengendalian intern berpengaruh signifikan dan positif terhadap perilaku etis karyawan. Sehingga hipotesis pertama yang menyatakan bahwa terdapat pengaruh yang signifikan antara pengendalian intern terhadap perilaku etis kosultan dapat dibuktikan kebenarannya.

Hasil penelitian ini sejalan dengan teori yang dikemukakan oleh AICPA (1947) dalam Hesti Arlich Arifiyani (2012) menjelaskan bahwa pengendalian intern sangat penting antara lain untuk memberikan perlindungan bagi entitas terhadap kelemahan manusia, selain itu pengendalian intern yang efektif dapat mengurangi kemungkinan kesalahan dan tindakan yang tidak sesuai dengan aturan. Dengan demikian dalam perusahaan membutuhkan pengendalian intern yang efektif agar seluruh karyawan dapat bekerja dan bertindak sesuai dengan aturan yang berlaku atau berperilaku etis. Oleh karena itu, apabila pengendalian intern yang kuat akan mampu menurunkan tingkat kecenderungan kecurangan akuntansi, jika pengendalian internya lemah maka kecenderungan kecurangan akuntansi akan semakin besar.

Dapat disimpulkan bahwa pengendalian intern mempunyai pengaruh secara signifikan terhadap perilaku etis karyawan pada PD BPR Sukahaji Kabupaten Majalengka. Variabel pengendalian intern sangat berpengaruh dalam perilaku etis karyawan. 


\section{ENTREPRENEUR}

Jurnal Bisnis Manajemen Dan Kewirausahaan

Program Studi Manajemen Fakultas Ekonomika dan Bisnis Universitas Majalengka

Published every January and July e-ISSN : (Proses), p-ISSN: 2723-1941

Available online https://ejournal.unma.ac.id/index.php/entrepreneur

\section{Pengaruh Kepatuhan Terhadap Perilaku} Etis Karyawan Dalam Sistem Penggajian

Hasil penelitian variabel kepatuhan terhadap perilaku etis karyawan dalam sistem penggajian dengan nilai $\mathrm{t}$ hitung $<\mathrm{t}$ tabel yaitu $0,831<2,002$ dan nilai signifikansinya 0,410 $>0,05$ maka Ho diterima dan Ha ditolak Hal ini berarti kepatuhan tidak berpengaruh signifikan terhadap perilaku etis karyawan dalam sistem penggajian. Hal ini berarti kepatuhan tidak berpengaruh signifikan terhadap perilaku etis karyawan dalam sistem penggajian pada karyawan sehingga hasil hipotesis kedua tidak terbukti kebenarannya.

Hasil penelitian ini tidak konsisten dengan penelitian Siti Aisah (2010) yang melakukan penelitian di 6 perusahaan, menyebutkan bahwa variabel kepatuhan berpengaruh positif terhadap perilaku etis karyawan dalam sistem penggajian. Sehigga hipotesis kedua yang menyatakan bahawa terdapa pengaruh yang signifikan anatara kepatuhan terhadap perilaku etis karyawan dalam sistem penggajian dapat dibuktikan kebenarannya.

Hasil penelitian ini tidak sejalan dengan teori yang dikemukakan oleh Roberts et al., (2002:23) dalam Hesti Arlich Arifiyani (2012) berpendapat bahwa cara profesi diorganisir, melalui antara lain kode etik dan ketaatan atas aturan akuntansi, akan memberikan pengaruh serta mengendalikan perilaku manajemen perusahaan. Dipatuhinya aturan dan kode etik oleh karyawan akan meningkatkan perilaku etis dalam suatu perusahaan. Kepatuhan juga memberikan dampak dalam menyediakan informasi laporan keuangan yang relevan. Hal tersebut mengindikasikan bahwa semakin karyawan patuh pada aturan akuntansi, maka karyawan akan semakin patuh dalam meningkatkan perilaku etisnya di dalam perusahaan.

Kepatuhan dalam bekerja dapat meminimalisir dalam kegagalan dalam penyusunan laporan keuangan yang disebabkan ketidaktaatan pada aturan akuntansi. Dengan demikian, semakin karyawan patuh dalam peraturan-peraturan dan kebijakan yang berlaku, baik yang ditetapkan oleh pihak intern perusahaan maupun pihak ekstern, maka semakin cepat dan tepat dalam menyelesaikan pekerjaan tersebut.

Dapat disimpulkan bahwa kepatuhan tidak mempunyai pengaruh secara signifikan terhadap perilaku etis karyawan pada PD BPR Sukahaji Kabupaten Majalengka.

\section{Pengaruh Integritas Manajemen Terhadap Perilaku Etis Karyawan Dalam Sistem Penggajian}

Hasil penelitian variabel integritas manajemen terhadap perilaku etis karyawan dalam sistem penggajian dengan nilai $t_{\text {hitung }}>$ $\mathrm{t}$ tabel yaitu 4,056>2,002 dan nilai signifikansinya $0,000<0,05$ maka Ho ditolak dan $\mathrm{Ha}$ diterima. Hal ini berarti integritas manajemen tidak berpengaruh signifikan terhadap perilaku etis karyawan dalam sistem penggajian. Hal ini berarti integritas manajemen berpengaruh signifikan terhadap perilaku etis karyawan dalam sistem penggajian pada karyawan sehingga hasil hipotesis ketiga terbukti kebenarannya.

Hasil penelitian ini konsisten dengan penelitian Siti Aisah (2010) yang melakukan penelitian di 6 perusahaan yang sudah go public maupun tidak dimana variabel integritas manajemen berpengaruh terhadap perilaku etis karyawan dalam sistem penggajian. Sehingga hipotesis ketiga yang menyatakan bahwa terdapat pengaruh yang 


\section{ENTREPRENEUR \\ Jurnal Bisnis Manajemen Dan Kewirausahaan}

Program Studi Manajemen Fakultas Ekonomika dan Bisnis Universitas Majalengka

Published every January and July e-ISSN : (Proses), p-ISSN: 2723-1941

Available online https://ejournal.unma.ac.id/index.php/entrepreneur

signifikan antara integritas manajemen terhadap perilaku etis karyawan dalam sistem penggajian dapat dibuktikan kebenarannya.

Hasil penelitian ini sejalan dengan teori
dalam
Siti
Aisah
(2010),

Pertanggungjawaban adalah kewajiban semua manajer dalam rangka menunjukan bahwa mereka telah memenuhi tanggung jawabnya dan telah menggunakan sumber daya yang dipercayakan kepada mereka. Semakin manajemen memiliki tingkat integritas yang tinggi, semakin rendah perilaku tidak etisnya, oleh karena itu, apabila manjemen dapat mengkomunikasikan nilai integritas dan etika melalui tindakan individual mereka, maka nilai-nilai tersebut diamati oleh karyawan. Hal itu berarti tingkat integritas manajemen yang tinggi akan memacu perilaku etis para karyawannya.

Dapat disimpulkan bahwa integritas manajemen mempunyai pengaruh secara signifikan terhadap perilaku etis karyawan pada PD BPR Sukahaji Kabupaten Majalengka. Variabel integritas manajemen sangat berpengaruh dalam perilaku etis karyawan.

\section{Pengaruh Pengendalian Intern, Kepatuhan dan Integritas Manajemen terhadap Perilaku Etis Karyawan Dalam Sistem Penggajian}

Hasil penelitian variabel pengendalian intern, kepatuhan dan integritas manajemen secara simultan terhadap perilaku etis karyawan dalam sistem penggajian dengan nilai sig. (signifikan) diperoleh sig 0,000 lebih kecil dari profitabilitas 0,05 atau $0,05>$ 0,000 dan nilai $\mathrm{F}_{\text {hitung }}>\mathrm{F}_{\text {tabel }}$ yaitu $8,993>$ 2,77 maka Ho ditolak dan Ha diterima. Hal ini berarti pengendalian intern, kepatuhan dan integritas manajemen bersama-sama berpengaruh secara signifikan terhadap perilaku etis karyawan dalam sistem penggajian.

Dapat disimpulkan bahwa pengendalian intern, kepatuhan dan integritas manajemen merupakan faktor-faktor yang cukup penting dalam mendorong karyawan untuk berperilaku etis. Pengendalian intern dapat mempengaruhi perilaku etis karyawan dimana seorang karyawan memiliki perilaku etis yang tinggi dapat memicu seorang karyawan untuk melaksanakan pekerjaan dengan baik mampu meminimalisir terjadinya kecurangan. Kepatuhan juga memberikan dampak dalam perilaku etis karyawan. kepatuhan juga membantu akan sangat mempengaruhi tingkat perilaku etis karyawan, dengan seseorang patuh dengan peraturan yang ada di dalam perusahaan maka dapat mencegah terjadinya kecurangan, yang nantinya akan membantu perusahaan untuk menyediakan informasi laporan keuangan perusahaan secara objektif kepada pihak yang berkepentingan. Integritas manajemen merupakan hal yang penting untuk dipertimbangkan karena semakin manajemen memiliki tingkat integritas yang tinggi, semakin rendah perilaku tidak etisnya, oleh karena itu, apabila manjemen dapat mengkomunikasikan nilai integritas dan etika melalui tindakan individual mereka, maka nilai-nilai tersebut diamati oleh karyawan. Hal itu berarti tingkat integritas manajemen yang tinggi akan memacu perilaku etis para karyawannya.

Sehingga hasil hipotesis empat diterima yaitu bahwa terdapat pengaruh yang positif dan signifikan antara pengendalian intern, kepatuhan dan integritas manajemen secara simultan terhadap perilaku etis karywan dalam sitem penggajian dapat dibuktikan kebenarannya. 


\section{ENTREPRENEUR}

Jurnal Bisnis Manajemen Dan Kewirausahaan

Program Studi Manajemen Fakultas Ekonomika dan Bisnis Universitas Majalengka

Published every January and July e-ISSN : (Proses), p-ISSN: 2723-1941

Available online https://ejournal.unma.ac.id/index.php/entrepreneur

\section{SIMPULAN DAN IMPLIKASI}

Setelah melakukan analisis dan pengujian hipotesis pengaruh pengendalian intern, kepatuhan dan intergritas manajemen terhadap perilaku etis karyawan dalam sistem penggajian pada Perusahaan Daerah Bank Perkreditan Rakyat (PD BPR) Sukahaji Kabupaten Majalengka, maka penelitian ini mengambil kesimpulan :

1. Hasil penelitian menunjukan variabel pengendalian intern berpengaruh signifikan dan positif terhadap perilaku etis karyawan dalam sistem penggajian. Hal ini berarti karyawan pada PD BPR Sukahaji Kabupaten Majalengka memiliki pengendalian intern yang baik

2. Hasil penelitian variabel kepatuhan terhadap perilaku etis karyawan dalam sistem penggajian dengan menyatakan bahwa variabel kepatuhan tidak berpengaruh signifikan terhadap perilaku etis karyawan dalam sistem penggajian. Hal ini terjadi berarti semakin taat perusahaan pada aturan akuntansi, semakin rendah perilaku tidak etis manajemen perusahaan. Karena kepatuhan merupakan pemeriksaan untuk mengetahui apakah prosedur dan aturan yang telah ditetapkan otoritas berwenang sudah ditaati oleh personel di organisasi tersebut.

3. Hasil Penelitian menunjukkan bahwa variabel integritas manajemen berpengaruh signifikan terhadap perilaku etis karyawan dalam sistem penggajian. Hal ini berarti karyawan pada karyawan PD BPR Sukahaji Kabupaten Majalengka memiliki integritas manajemen yang baik.

4. Hasil Penelitian menunjukkan bahwa variabel pengendalian intern, kepatuhan dan integritas manajemen secara simultan berpengaruh signifikan dan positif terhadap perilaku etis karyawan dalam sistem penggajian pada karyawan PD BPR Sukahaji Kabupaten Majalengka. Sehingga dapat disimpulkan bahwa pengendalian intern, kepatuhan dan integritas manajemen merupakan faktor-faktor yang cukup penting dalam meningkatkan karyawan berperilaku etis. Jika salah satu diantara variabel tersebut tidak dimiliki oleh karyawan maka akan berpengaruh terhadap menurunya perilaku etis karyawan.

\section{DAFTAR PUSTAKA}

Hesti ArlichArifyani. 2012. Pengaruh pengendalian internal, kepatuhan dan kompensasi manajemen terhadap perilaku etis karyawan. Jurnal: Universitas Negeri Yogyakarta. Vol 1 No 1, Tahun 2012

https://koran.tempo.co/ 2019 di akses hari senin 8 Februari 2021

Mohammad Glifandi Hari Fauwzi, 2011, "analisis pengaruh kefektifan pengendalian internal, presepsi kesesuaian kompensasi, moralitas manajemen terhadap perilaku tidak etis dan kecenderungan kecurangan akuntansi" Universitas Diponogoro, Semarang.

Ni Putu Indah Jayanti dan Ni ketut Rasmini, 2013 "pengaruh pengendalian intern,motivasi dan reward manajemen pada perilaku etis konsultan" Univeristas Udaya. Bali

Nur Ratri Kusumastuti, 2012. Analisis Faktor-Faktor Yang berpengaruh 


\section{ENTREPRENEUR \\ Jurnal Bisnis Manajemen Dan Kewirausahaan}

Program Studi Manajemen Fakultas Ekonomika dan Bisnis Universitas Majalengka

Published every January and July e-ISSN : (Proses), p-ISSN: 2723-1941

Available online https://ejournal.unma.ac.id/index.php/entrepreneur

Terhadap Kecenderungan

Kecurangan Akuntansi Dengan

Perilaku Tidak Etis Sebagai Variabel

Intervening. Skripsi: Universitas

Diponegoro Semarang.

Ricky Griffin dan Ronald J. Ebert 2006.

Manajemen Jilid 1. Penerbit

Erlangga. Jakarta.

Siti, Aisah 2010. Pengaruh Pengendalian

Intern, Kepatuhan dan Integritas

Manajemen terhadap Perilaku Etis

Karyawan dalam Sistem Penggajian.

Skripsi: Universitas Pembangunan

Nasional Veteran.

Sugiyono.2012. Metode Penelitian

Kuantitatif Kualitatif dan $R \& D$.

Alfabeta. Bandung.

---------.2014. Metode Penelitian

Kuantitatif Kualitatif dan RND.

Alfabeta. Bandung

Sukrisno Agoes dan Jan Hoesada. 2009.

Bunga Rampai Auditing. Jakarta:

Salemba Empat.

Sukrisno,Agoes. 2012. Auditing ( Petunjuk

Praktis Pemeriksaan Akuntan oleh

Akuntan publik) Edisi 4 Buku 1.

Lembaga Penerbit Salemba Empat.

Jakarta. 